\title{
IMPLEMENTASI PEMBENTUKAN KARAKTER MULTIKULTURAL SANTRI PONDOK PESANTREN RIYADLUS SHOLIHIN KOTA PROBOLINGGO
}

\author{
Achmad Muzairi Amin \\ Institut Pesantren KH Abdul Chalim Mojokerto, Indonesia \\ Email: muzairi.amin@gmail.com
}

\begin{abstract}
Abstrak: Artikel ini akan menguraikan tentang implementasi pembentukan karakter multikultural santri di Pondok Pesantren Riyadlus Sholihin Kota Probolinggo. Pesantren ini menerapkan sistem pengajaran tradisional dan campuran dengan mengintegrasikan atau memadukan sistem kurikulum diniyah dengan sistem pendidikan nasional (sisdiknas). Dengan latar belakang santri yang multikultural, pesantren terus berupaya melakukan langkah-langkah variatif mewujudkan SDM berkualitas, terutama dalam memformulasikan implementasi pembentukan karakter multikultural dari generasi ke generasi. Pendekatan deskriptif kualitatif dipilih dalam penelitian ini. Pengumpulan data diperoleh melalui observasi, dokumentasi, wawancara, dan triangulasi. Hasil dari penelitian menyatakan bahwa pertama; perencanan pembentukan karakter multikultural santri di Pondok Riyadlus Sholihin direncanakan berdasarkan tujuan, visi dan misi pesantren yang jelas, serta terintegrasi dengan muatan kurikulum pesantren berbasis kitab salaf dalam semua proses pembelajaran baik di dalam kelas maupun di luar kelas. Kedua; implementasi pembentukan karakter multikultural dikalangan santri dilakukan secara masif dan intensif (istiqamah) melalui pendidikan formal dan non formal serta kegiatan ekstrakurikuler dan takhassus baik secara harian, mingguan, bulanan maupun tahunan. Hal inilah yang menjadi ciri khas terwujudnya karakter multikultural santri pesantren Riyadlus Sholihin. Kegiatan-kegiatan yang dilaksanakan dimaksudkan selalu menunjang penguatan religiusitas dan spiritualitas, serta selaras dengan nilai-nilai pendidikan karakter.

Kata kunci: Pembentukan Karakter, Multikultural Santri, Pondok Pesantren
\end{abstract}

\section{Pendahuluan}

Bagaimanapun pendidikan pesantren adalah pendidikan tertua yang pernah ada di Indonesia dan dianggap sebagai produk budaya Indonesia yang indigeneous. ${ }^{1}$ Karenanya hingga hari ini, pesantren menjadi salah satu wadah yang penting dalam pendidikan Islam terutama aspek multikultural di dalamnya. Hal tersebut dapat terjadi disebabkan oleh banyak faktor. Maisah dkk., menyebutkan dalam penelitiannya bahwa nilai-nilai karakter sosial siswa yang ada di pondok pesantren dapat mempengaruhi pola internalisasi tradisi di pondok, yang bisa ditanamkan di pendidikan boarding school baik di madrasah maupun di pesantren. ${ }^{2}$

Pesantren dengan kemajemukannya telah mampu beradaptasi dalam lingkungan internalnya bahkan mampu menciptakan generasi yang mumpuni dan teruji di tengah masyarakat.

\footnotetext{
${ }^{1}$ Ahmad Ihwanul Muttaqin, "Modernisasi Pesantren Modernisasi Pesantren; upaya Rekonstruksi Pendidikan Islam (Studi Komparasi Pemikiran Abdurrahman Wahid dan Nurcholish Madjid), "Tarbiyatuna: Jurnal Pendidikan Islam", vol.7, no. 2 (Agustus, 2014 ), $67 . \quad$ Lihat https://ejournal.iaisyarifuddin.ac.id/index.php/tarbiyatuna/article/view/55/61

2 Maisah dkk., "Pendidikan Multikultural Pesantren dan Boarding School; Studi terhadap Pesantren Salafy dan Madrasah Berasrama non-Pesantren di Jambi," Jurnal Manajemen Pendidikan dan Ilmu Sosial, 1(1), 1-8. https://doi.org/10.38035/jmpis.v1i1.118. 
Karena itu, Gus Dur dalam M. Hasyim menyebut pesantren sebagai subkultur dari budaya Nusantara. ${ }^{3}$

Pesantren merupakan aset pendidikan yang bisa bertahan di era modernitas, ${ }^{4}$ yang membawa nilai-nilai multikulturalisme, pluralisme, inklusifisme, dan yang lainnya. Karena itulah pesantren dengan khasnya selalu berusaha menjaga eksistensi, dinamika, dan bahkan melakukan transformasi di berbagai bidang untuk bekal kehidupan di masyarakat. ${ }^{5}$ Sebab itu, menurut $\mathrm{KH}$. Said Aqil Siradj dalam Hasyim, tidak mengherankan kalau kehadiran pesantren memiliki tujuan utama adalah untuk menyebarluaskan ajaran universalitas agama Islam ke seluruh penjuru nusantara. ${ }^{6}$ Pesantren dikategorikan lembaga non formal Islam, karena kurikulum yang dirancang oleh setiap unsur pesantren bersifat mandiri, dengan program-program pendidikan yang dimanajemen sendiri dan pada umumnya bebas dari pedoman formal. ${ }^{7}$ Dalam rangka membentuk dan mewujudkan karakter para santri menjadi generasi penerus yang patut dibanggakan.

Pembentukan karakter multikultural di kalangan santri Pondok Pesantren Riyadlus Sholihin berimplikasi pada karakter multikultur santri yang sangat berpengaruh dalam proses kehidupan pesantren. Memang secara implementasi belum sepenuhnya dapat dicapai, semua tergantung pada implementasiannya. Implementasi pembentukan karakter multikultural diawali dengan perencanaan kemudian merumuskan dalam muatan kurikulum karakter yang bersumber dari al-Qur'an dan kitab klasik (kitab kuning), dan pengintegrasian dalam seluruh komponen kelembagaan di dalam pesantren, sehingga bisa terwujud spiritualitas yang kuat, berorientasi pada keunggulan dan kesadaran yang tinggi ditengah-tengah keberagaman/multikultur yang ada.

Pondok Pesantren Riyadlus Sholihin berada di Jalan Lawu nomor 39 Ketapang, Kecamatan Kademangan, Kota Probolinggo. Hingga kini Pondok Pesantren Riyadlus Sholihin telah berusia sekitar 49 tahun (1971-2020), sejak masa rintisan Habib Muhammad Al Habsyi tahun 1971 sampai 2005, lalu dilanjutkan generasi penerus Habid Ali tahun 2005 sampai sekarang, banyak prestasi yang sudah diraih dan diperoleh. Intinya, kepercayaan masyarakat terhadap pondok pesantren tidak dapat diragukan lagi. Betapa optimis dan semangat para walisantri menitipkan anak-anak mereka untuk belajar dan mengabdikan diri di pesantren. Pondok pesantren menjadi wadah dan tempat para orang tua menggapai impian dan harapan agar anak-

\footnotetext{
${ }^{3}$ Muhammad Hasyim, "Modernisasi Pendidikan Pesantren dalam Perspektif KH. Abdurrahman Wahid," Cendekia; Jurnal Studi Keislaman, Vol. 2, No. 2, (Desember 2016), 170. Lihat juga Abdurrahman Wahid, Menggerakkan Tradisi, Esai-Esai Pesantren (Yogyakarta: LKiS, 2001), 10.

4 Ali Muchasan, “Pendidikan Islam Multikultural di Pesantren”, Inovatif, Vol. 4, No. 1 Pebruari 2018, 86-87.

${ }_{5}^{5}$ Muhammad Hasan, "Inovasi dan Modernisasi Pendidikan Pondok Pesantren", KARSA: Jurnal Sosial dan Budaya Keislaman, Vol. 23, No, 2, Desember 2015, 304.

${ }^{6}$ Hasyim, "Modernisasi Pendidikan", 170.

${ }^{7}$ Moh. Rofie, "Manajemen Kurikulum Pendidikan Agama Islam Berbasis Pesantren”, Jurnal Reflektika, Vol. 12, No. 2, Juli-Desember 2017, 42.
} 
anaknya kelak bisa menjadi generasi yang sukses dunia dan akhirat. Terutama para wali santri dari kalangan kota Probolinggo; Kademangan, Mayangan, Kanigaran, Kedopok, dan Wonoasih.

Pondok Pesantren Riyadlus Sholihin sebagaimana pondok pesantren lain pada umumnya bergerak dalam tiga bidang tersebut di atas. Sebagai konsekwensi logis tahapan berikutnya adalah mengadakan lembaga pendidikan baik formal maupun non-formal. Lembaga pendidikan di pesantren ini telah di mulai dari tingkat Taman Kanak-kanak (TK) sampai perguruan tinggi. Lembaga tersebut ada yang berafiliasi kepada Kementerian Agama dan kepada Kementerian Pendidikan dan Kebudayaan (Kemendikbud). Untuk pendidikan non formal atau madrasah diniyah (madin) ada Ula, Wustho sampai Ulya. Setiap santri yang telah dinyatakan lulus kelas Wustho wajib melakukan tugas pembelajaran diluar pesantren selama kurang lebih satu tahun. Pendirian lembaga-lembaga tersebut dimaksudkan agar masing-masing santri dapat memilih dan menyeleksi sekolah sebagai tempat belajar yang berdasarkan pada bakat dan minat serta kemampuan diri.

Dalam proses risetnya, artikel ini menggunakan metode kualitatif dengan pendekatan deskriptif-kualitatif. Sumber data primer adalah Kepala Pesantren, Pengurus Pesantren dan Ustad serta warga pondok di Pondok Pesantren Riyadlus Sholihin Kota Probolinggo. Sedangkan data sekunder meliputi semua data selain primer yang mendukung terhadap kebutuhan data yang diperlukan. Adapun teknik pengumpulan data melalui dokumentasi observasi, dan wawancara. Wawancara dalam penelitian ini dilakukan kepada para pemberi informasi yang relevan antara lain; ustadz Hafidz, Alif Ibrahim, Ahmad Sya'ir, Suhlal Hadi, Abdul Manap, Misbahul Munir, Farihin, Toha Maksum, Ustadz Qodir dan M. Khoiruddin.

\section{Pendidikan Karakter dan Multikultural}

Konsep pembentukan karakter dapat dipahami sebagai proses pendidikan karakter dengan melakukan pembiasaan kepada setiap individu baik yang terkait dengan sikap, perilaku, motivasi dan seterusnya yang bisa menjadikan setiap individu menjadi pribadi yang lebih baik. Manusia telah diciptakan dengan keadaan sempurna seperti dalam karakternya, namun dalam perjalanan hidup sebagian ada yang mengalami degradasi (kemerosotan) ke dalam perilaku yang sangat tercela dan hina (asfala safilin). ${ }^{8}$ Sebaliknya, sebagian yang lain tetap berada dalam hidup yang baik dan berkarakter positif, menjalani hidup dengan didasari keimanan dan amal sholeh. Dalam alQur'an surat al-'Alaq ayat 4-6 dijelaskan yang artinya

\footnotetext{
${ }^{8}$ Maskuri Bakri \& Diyah Werdiningsih, Membumikan Nilai Karakter Berbasis Pesantren (Jakarta: Nirmana Media, 2017), 3. 
“... yang mengajar (manusia) dengan pena, Dia mengajarkan manusia tentang apa yang tidak. diketahuinya, dan sekali-kali tidak! Sungguh, manusia itu benar-benar melampaui batas.'

Karena itu terbentuknya karakter personal ditentukan dua faktor yaitu nature (alami atau fitrah) dan nurture (melalui pendidikan dan sosialisasi). ${ }^{10}$ Lebih lanjut, Mashuri mengatakan bahwa karakter terbentuk dipengaruhi paling sedikit 5 faktor yaitu: (1) temperamen dasar (dominan, intim, stabil, cermat), (2) keyakinan (paradigma), (3) pendidikan (wawasan atau pengetahuan kita), (4) motivasi atau semangat hidup dan (5) perjalanan (pengalaman masa lalu, lingkungan dan pola asuh).

Pendidikan karakter mengarah pada nilai-nilai seperti jujur, peduli, rasa hormat, tanggungjawab, dan adil- dan membantu peserta didik untuk memahami, memperhatikan, dan mengamalkan nilai-nilai tersebut dalam semua aspek kehidupan. Menurut Lickona dalam Sudrajat, sedikitnya ada tujuh indikator dan atau alasan pentingnya pendidikan karakter diajarkan, yaitu: ${ }^{11}$

Pertama; merupakan cara terbaik untuk menjamin peserta didikberkepribadian baik dalam kehidupannya. Kedua; merupakan cara dalam meningkatkan prestasi akademiknya. Ketiga; sebagian peserta didik tidak mampu membentuk karakter kuat bagi dirinya di tempat lain. Keempat; sebagai persiapan untuk menghormati orang lain ditengah kehidupan masyarakat yang multikultur. Kelima; Berangkat dari akar permasalahan yang berkaitan dengan problematika moral-sosial, seperti ketidakjujuran, kekerasan, ketidaksopanan, pelanggaran kegiatan seksual, dan sebagainya. Keenam; Persiapan terbaik menyongsong perilaku di lingkungan tempat bekerja. Ketujuh; Pembelajaran nilai-nilai budaya yang menjadi bagiandari sebuah peradaban.

Doni Koesoema A. dalam Ningsih menyarankan penggunaan metode-metode intergral dalam pendidikan karakter, agar pendidikan karakter itu dapat dikatakan sebagai sesuatu yang integral atau utuh. ${ }^{12}$ Menurutnya ada lima unsur yang bisa dijadikan metodologi pendidikan karakter yang intergral tersebut, tiga diantaranya yaitu; (1) Pengajaran yaitu mengajarkan nilai-nilai karakter sehingga peserta didik mempunyai gagasan konseptual tentang nilai-nilai sebagai pemandu sikap dan perilaku dalam mengembangkan karakter diri pribadi. (2) Ada keteladanan dari pendidik dan tenaga kependidikan yang memiliki peran sebagai model atau contoh bagipara peserta didik dalam memahami nilai-nilai dimaksud; dan (3) diperlukan adanya prioritas dalam pendidikan karakter.

\footnotetext{
${ }^{9}$ Al-Qur'an, 96: 4-6.

${ }^{10}$ Bakri \& Werdiningsih, Membumikan Nilai Karakter, 4

11 Ajat Sudrajat, “Mengapa Pendidikan Karakter”, Jurnal Pendidikan Karakter, Vol. 1, No. 1, Tahun 2011, 49

12 Tutuk Ningsih, Implementasi Pendidikan Karakter, cetakan pertama (Purwokerto: STAIN Press, 2015), 62
} 
Sedangkan pendidikan multikultural dipahami sebagai sebuah pendekatan yang lebih sesuai dan relevan bagi masyarakat Indonesia yang heterogen. Bahwa terkait kenyakinan dan agama sudah dijelaskan secara gamblang dalam Undang-undang; baik UUD 1945, UU nomor 39 tahun 1999 dan seterusnya. Wacana tentang paham multikultural (multikulturalisme) dalam konteks pendidikan saat ini, tetap menjadi isu penting dan krusial dalam upaya pembangunan masyarakat harmonis di Indonesia. ${ }^{13}$

Sebagaimana dipahami pendidikan multikultural menititberatkan padapembahasanpembahasan seperti kemiskinan, ketidakadilan, penindasan, dan keterbelakangan kelompok minoritas dalam berbagai aspek; sosial, Ekonomi, budaya, pendidikan, dan lain sebagainya. ${ }^{14}$ Terlebih pendidikan multikultural merupakan wacana baru dengan latar sejarah diskriminasi dan konflik masyarakat, baik dalam lingkup umum maupun dalam pendidikan. ${ }^{15}$ Pendidikan multikultural adalah proses pengembangan seluruh potensi manusia yang menghargai pluralitas dan heterogenitas sebagai konsekuensi keragaman etnis, suku, budaya, dan kepercayaan atau agama. ${ }^{16}$ Menurut Gorski dalam Zulkarnain pendidikan multikultural mencakup tiga hal transformasi, yaitu: Transformasi diri, Transformasi sekolah dan proses belajar mengajar, dan Transformasi masyarakat. ${ }^{17}$ Sedangkan menurut Huzaimah, pendidikan multikultural adalah strategi pendidikan yang harus diaplikasikan pada semua jenis mata pelajaran. Hal itu bisa dilakukan agar proses belajar menjadi efektif dan mudah dengan cara mempergunakan perbedaan-perbedaan budaya yang sudah ada pada peserta didik seperti perbedaan agama, bahasa, gender, etnis, kelas sosial, ras, kemampuan, dan umur. ${ }^{18}$ Pendidikan multikultural juga dapat melatih, membiasakan dan membangun karakter peserta didik agar mampu bersikap lebih humanis, demokratis, dan pluralis dalam lingkungan.

\section{Perencanaan Pembentukan Karakter Multikultural Santri}

Karakter multikultural para santri yang memang variatif seperti asal usul keluarga, dan budaya lokal yang cukup beragam dengan segala keunggulan dan keunikan masing-masing. Maka dalam konteks ini pesantren memiliki dua potensi yakni potensi pengembangan masyarakat dan potensi pendidikan ${ }^{19}$. Perencanaan dipahami sebagai sesuatu hal yang cukup penting dalam

\footnotetext{
${ }^{13}$ Laurencia Primawati,"Pembelajaran Multikultural melalui Pendidikan Multikultural Berbasis Nilai Kebangsaan", JUPIIS, Vol. 5, No. 2, Desember 2013, 82.

14 Rustam Ibrahim, "Pendidikan Multikultural: Pengertian, Prinsip dan Relevansinya dengan Tujuan Pendidikan Islam”, ADDIN, Vol. 7, No. 1, Februari 2013.

15 Titin Nur Afidah, "Konsep dan Paradigma Pendidikan Multikultural: Studi Analisis Undang-Undang Republik Indonesia Nomor 20 Tahun 2003 Tentang Sistem Pendidikan Nasional”, Skripsi (Malang: UMM, 2017).

${ }^{16}$ Ibrahim, "Pendidikan Multikultural, 4

17 Zulkarnain Dali, "Pendidikan Islam Multikultural”, Nuansa, Vol. X, No.1, Juni 2017, 12

${ }^{18}$ Huzaimah, "Imlementasi Nilai-Nilai Pendidikan Multikultural dalam Pembelajaran PAI; Telaah terhadap Hidden Curriculum di SMAN 1 dan SMAN 2 Grabag". Thesis Program Pascasarjana (Jawa Tengah: IAIN Salatiga, 2018), 8

${ }^{19}$ Muhammad Sulton Fatoni, Kapital Sosial Pesantren (Jakarta: UI Press, 2015), 75

50 | Tarbiyatuna: Jurnal Pendidikan Islam; Volume 14, Nomor 1, Februari 2021 p-ISSN: 2085-6539; e-ISSN: 2242-4579, 46-68
} 
mencapai sebuah tujuan tertentu. Dengan perencanaan yang baik dan tepat berbagai kegiatan dan aktivitas akan terealisasi secara lebih optimal. Bahkan dapat dikatakan bahwa suatu perencanaan yang matang dan sistematis merupakan tahapan paling awal dalam aspek manajemen. Diantara pendekatan perencanaan yang cukup efektif adalah perencanaan strategik. Perencanaan strategik ini ditandai dengan adanya penentuan dan pemahaman terhadap visi misi. Visi dan misi yang baik menjadi penentu arah yang jelas dalam kegiatan terprogram. Dengan kata lain, perencanaan yang tertuang dalam visi misi sekaligus menjadi unsur paling utama dan pertama yang harus ada, karena dari sanalah munculnya berbagai tujuan dan program kegiatan sistematis.

Perencanaan pondok pesantren Riyadlus Sholihin Ketapang Kota Probolinggo antara lain adalah sebagai berikut: (1) melakukan perencanaan dengan tujuan, visi dan misi yang jelas dalam pembentukan karakter multikultural, (2) merumuskan tujuan, tata tertib, larangan, sanksi, kewajiban dan proses pelaksanan pendidikan untuk membentuk karakter multikultural, (3) merumuskan kurikulum yang memuat pelajaran karakter bersumber dari kitab-kitab akhlak, (4) merancang strategi dan mempertahankan kitab kuning sebagai sumber pembentukan akhlak/karakter multikultural, (5) merencanakan bentuk-bentuk kegiatan pembentukan karakter multikultural yang integratif atau terpadu.

Terdapat sedikitnya tiga hal tujuan pondok pesantren Riyadlus Sholihin yang mempengaruhi cara pandang para pengurus dan segenap walisantri serta masyarakat sekitar. Tujuan pertama adalah menampung anak-anak fakir miskin khususnya yatim-piatu. Tujuan pesantren tersebut mengisyaratkan betapa seriusnya pengasuh dan pengelola pesantren dalam mempersiapkan generasi unggul melalui pendidikan berkelanjutan di lingkungan pondok pesantren. Hal tersebut selaras dengan pernyataan Masyhud dan Khusnurdilo dalam Cahyono, tentang sistem pendidikan di lembaga pesantren secara menyeluruh, meliputi: prinsip-prinsip pendidikan, materi pelajaran dan metode pengajaran, sarana dan tujuan pendidikan, kehidupan santri dan kiai serta hubungan diantara keduanya. ${ }^{20}$

Pondok pesantren yang berada di bawah naungan Yayasan Pendidikan dan Tarbiyatul Aytam Sayyid Muhammad bin Alwi al Maliki al Hasani Riyadlus Sholihin ini seakan menegaskan terhadap terbentuknya karakteristik yang khas dalam mewujudkan karakter manusia, sebagaimana disebutkan Maskuri dan Werdiningsih bahwa karakter ditentukan pada dua faktor antara nature (alami) dan nurture (sosialisasi dan pendidikan). Keberadaan pondok pesantren yang diprioritaskan kepada para kaum dhu'afa dan fakir miskin secara tersirat merupakan sosialisasi kepada masyarakat luas (khususnya sesama muslim) bahwa agama Islam memerintahkan untuk memperhatikan dan

${ }^{20}$ Heri Cahyono, "Pendidikan Multikultural di Pondok Pesantren: Sebagai Strategi dalam Menumbuhkan Nilai Karakter”, At-Tajdid, Vol. 1 , No. 1, Januari-Juni 2017, 36 
memperlakukan para fakir miskin dengan sebaik-baiknya. Bahkan mendidik mereka dengan cara yang bijaksana selayaknya mendidik para santri pada umumnya.

Perencanaan pembentukan karakter multikultural santri direncanakan dalam tiga kelompok, yaitu a) terpadu dalam pembelajaran pada kurikulum pondok melalui muatan kurikulum pesantren yang di kembangkan dalam konteks baik pendidikan formal yang berbasis kitab kuning atau dirasah Islamiyah (kitab keislaman berbahasa Arab), Fiqih, al-Qur'an, Ilmu Tasawwuf, dan pendidikan non-formalnya, b) terpadu dengan managemen lembaga-lembaga naungan pesantren, dan c) terpadu melalui kegiatan ekstrakurikuler. Dalam Ma'arif \& Cahyani ${ }^{21}$ diuraikan tentang Character Education Quality Standards yang merekomendasikan 11 prinsip dalam mewujudkan karakter yang efektif, diantaranya adalah dengan pendekatan yang proaktif tajam, dan efektif. Dikarenakan untuk membentuk karakter multikultural, secara mendasar tidak hanya diterapkan pada pendidikan formal semata. Melainkan juga harus diterapkan pada pendidikan nonformal dan informal.

Pesantren membentuk karakter melalui pendidikan formal diniyah, dengan menanamkan dan memperkuat keimanan dan ketakwaan, menyemaikan akhlak mulia. Dengan pendidikan non-formalnya pesantren membentuk karakter multikultural dengan memperioritaskan pemahaman toleransi, rendah hati, keseimbangan, moderat, dan cinta tanah air berdasarkan ajaran Islam, nilai luhur bangsa, serta berdasarkan semboyan Bhinneka Tunggal Ika, landasan ideal Pancasila dan Undang-Undang Dasar 1945 dan seterusnya.

Pendidikan dalam pesantren ini menekankan pada aspek keteladanan dalam membentuk karakter para santri. Nilai-nilai yang terkait dengan pembentukan karakter santri yang bersumber dari tradisi pesantren cukup kompleks, nilai-nilai yang ada secara kategoris terbagi kedalam 3 (tiga) kelompok, yaitu: nilai-nilai kebangsaan (al-Ukhuwwah al-Sya'biyyah), nilai-nilai hubungan antar manusia (al-Ukhuwwah al-Basyariyyah), dan nilai-nilai yang membentuk kepribadian santri atau (alakblaq al-Karimah). ${ }^{22}$

Pembentukan karakter multikultural dalam pembelajaran terkait dengan kurikulum yang dipergunakan. Karena kurikulum sebagai acuan bagi kemajuan dan arah lembaga pendidikan untuk merealisasikan semua program. Pondok Pesantren Riyadlus Sholihin menggunakan kurikulum yang disesuaikan dengan situasi dan kondisi para santri. Karena setiap santri memiliki latar belakang yang berbeda, sehingga pelajarannya tidak bisa disepadankan. Mengingat, pembentukan karakter merupakan sesuatu yang penting yang harus diajarkan, dipahamkan, dipraktekkan sampai pada akhirnya berhasil mencetak para santri yang memiliki kepribadian

21 Ma'arif dan Cahyani, “Pendidikan Multikultural Sebagai Pembentukan Karakter Peserta Didik”, Ta'lim: Jurnal Pendidikan Islam, Vol. 2, No. 2, 2019, 143

22 Bakri dan Werdiningsih, Membumikan Nilai Karakter, 16

52 | Tarbiyatuna: Jurnal Pendidikan Islam; Volume 14, Nomor 1, Februari 2021 p-ISSN: 2085-6539; e-ISSN: 2242-4579, 46-68 
mulia, berakhlak karimah, dan paripurna atau dalam istilah yang lain disebut insan kamil. Misalnya dalam meneladankan sikap penghormatan kepada ustadz dengan membiasakan diri 'mencium tangan', seperti yang disampaikan oleh ustad Tauhid:

"Pesantren ini lebih menekankan perilaku dan atau sikap keseharian. bagaimana berperilaku terpuji kepada orang tua, para asatidz, teman sebaya. Sikap yang paling ditekankan adalah tatakrama atau sopan-santun, baik dalam gerak-geriknya, cara berbicaranya, agar timbul sikap saling menghormati. Ketika bertemu dengan ustadz diajarkan agar mengucapkan salam dan berjabat tangan, entah di manapun atau kapan pun berada dibiasakan untuk berjabat tangan, ketika diruang kelas, dihalaman pondok atau dimana pun, sudah menjadi kebiasaan, kalau sehari ketemu 3 kali, ya berarti setidaknya sudah tiga kali berjabat tangan, bahkan bisa lebih, ini dilakukan sebagai bentuk ikhtirom (memuliakan guru), saya sudah melaksanakan itu sejak dulu, dan kini ketika saya bertemu dengan para santri, mereka tanpa disuruh sudah dengan sendirinya mendekat dan menerapkan tradisi berjabat tangan. Dengan begitu akan terbentuk adanya rasa hormat. ${ }^{23}$

Sebagai gambaran pentingnya pembentukan karakter yang diajarkan kepada peserta didik antara lain adanya sikap religius, toleransi dan semangat kebangsaan, cinta tanah air, cinta damai, peduli sosial dan seterusnya. Misalnya sikap peduli yang ditampilkan dalam pelaksanaan shalat ghaib korban longsor di Ponorogo pada tahun 2017.

"Pelaksanaan shalat ghaib dilanjutkan dengan tahlil dilaksanakan setelah shalat ashar untuk mendoakan para korban. Kami doakan para korban mendapatkan tempat terbaik di sisi Allah, dan keluarga yang ditinggalkan diberi ketabahan. Para santri juga berharap bencana tidak terjadi lagi, terutama di Probolinggo". ${ }^{24}$

Pelaksanaan shalat ghaib secara berjamaah di masjid pondok pesantren merupakan salah satu bentuk pendidikan karakter bagi para santri yang menjadi program pesantren secara insidentil dalam memberikan respon terhadap perkembangan lokal dan nasional.

Dengan demikian, dapat dikatakan bahwa perencanaan pembentukan karakter multikultural santri Pondok Pesantren Riyadlus Sholoihin memiliki keunikan tersendiri di mulai sejak kali pertama perintisan dan pendirian pesantren oleh Habib Muhammad selaku pengasuh pertama, yang kemudian diteruskan oleh generasi berikutnya Habib Ali dan Habib Hadi. Dan secara optimal adanya keberperanan pengurus dan pengelola pesantren dalam menerapkan dan mengimpelementasikan tujuan, visi dan misi pesantren secara terintegratif.

Begitu pula dalam visi dan misi pesantren Riyadlus Sholihin selaras dengan RPJPN (rencana pembangunan Jangka Panjang Nasional) tahun 200 sampai dengan 2025, yakni; terwujudnya karakter bangsa yang tangguh, berakhlak mulia, kompetitif, dan bermoral berdasarkan Pancasila, yang dicirikan dengan watak dan perilaku manusia dan masyarakat Indonesia yang beragam, beriman dan bertakwa kepada Tuhan Yang Maha Esa, bergotong-

${ }^{23}$ Tauhid, Wawancara, MA Riyadlus Sholihin, 10 Juni 2020.

${ }^{24}$ Abdul Manap, Wawancara, Probolinggo, 28 Juni 2020. 
royong, berbudi luhur, bertoleran, berjiwa patriotik, berkembang dinamis, dan berorientasi pengembangan ilmu pengetahuan dan teknologi. Jadi, pondok pesantren tidak hanya menekankan atau memfokuskan kepada pendidikan agama (kognitif) semata akan tetapi juga memberikan nilainilai lebih dalam pembentukan akhlak (psikomotorik) dan pengembangan potensi anak di dalam setiap pergaulan yang dilandasi sifat kekeluargaan dan tolong menolong. ${ }^{25}$

Karena itulah pesantren sejak dulu hingga sekarang masih dipercaya sebagai wadah menciptakan generasi masa depan yang tangguh, kompeten dan mampu menghadapi segala macam perubahan zaman. Sejatinya, segala perencanaan pembentukan karakter multikultural yang ada dipesantren telah berjalan sejak lama. Hal itu, diteladankan oleh para kiai, para pengurus pesantren dalam kehidupan sehari-hari.

Semua santri mendapatkan perlakukan khusus selama di pesantren. Para pengurus memberikan pelayanan pada kategori santri berkebutuhan khusus dari kalangan yatim piatu. Bahkan urusan kebutuhan harian para santri tersebut dipenuhi oleh pesantren. Karena sudah diteladankan oleh pengasuh pertama Habib Muhammad.

Asal santri dari berbagai suku menjadi ciri khas kalangan pesantren-pesantren besar di Jawa. Karena itu, para pengasuh dan pengurus pesantren juga mengantisipasi kesenjangan yang terjadi dengan melibatkan para santri dari beberapa daerah sebagai pembantu pengurus dalam memjembatani komunikasi dan interaksi antara sesama santri lintas daerah. Hal itu dilakukan, karena beragam bahasa daerah yang dipakai santri terkadang memicu kesalahpahaman antara sesama santri. Tidak jarang para pengurus menangani konflik internal santri yang terjadi setiap tahun dikala telah memulai pelaksanaan pembelajaran bagi para santri baru. Karena para santri baru membutuhkan penyesuaian yang cukup serius di pesantren.

Pelaksanaan kegiatan pesantren sepanjang observasi peneliti menitikberatkan kepada pendisiplinan santri dalam menjalan kegiatan keagamaan dan pembelajaran dikelas. Pengawasan dari pengurus pesantren cukup ketat, sehingga para santri mayoritas mengikuti kegiatan pesantren dengan wajar. Meskipun terdapat beberapa santri yang mendapatkan hukuman karena melakukan pelanggaran-pelanggaran ringan. Seperti, tidak memenuhi prosedur perijinan ketika tidak masuk dalam pembelajaran di kelas atau asrama dan setersunya. Pola umum yang diberlakukan di beberapa pondok pesantren umumnya adalah sistem pendidikan multikultur yang terpadu ke dalam tata aturan dan tata tertip pondok. Misalnya terkait penempatan atau pemondokan (asrama) santri. ${ }^{26}$ Pengembangan wawasan kebangsaan para santri dalam rangka membangun

25 Joan Ramadhan, "Upaya Pengurus Pondok Pesantren terhadap Penanaman Nilai-nilai Pendidikan Multikultural di Pondok Pesantren Hidayatul Mubtadiin Jati Agung Lampung Selatan", Skripsi Fakultas Tarbiyah dan Keguruan UIN Raden Intan Lampung 2019, 34

${ }^{26}$ Cahyono, Pendidikan Multikultural, 27.

54 | Tarbiyatuna: Jurnal Pendidikan Islam; Volume 14, Nomor 1, Februari 2021 p-ISSN: 2085-6539; e-ISSN: 2242-4579, 46-68 
nasionalisme pun tidak luput dari perhatian para pengurus pesantren. Seperti dalam pelaksanaan hari-hari besar Islam dan Nasional, dilaksanakan kegiatan nasional dalam rangka memperingati hari santri. Semuanya dilakukan atas dasar pemahaman agama yang baik.

\section{Implementasi Pembentukan karakter Multikultural Santri}

Implementasi pembentukan karakter disesuaikan dalam pola hidup santri dan pengurus di pesantren dilakukan pembiasaan. Santri dan pengurus melaksanakan rutinitas sebagaimana jadwal yang telah di sahkan oleh pesantren. Mulai bangun tidur sampai jadwal tidur kembali para santri melaksanakannya dengan disiplin, penuh tanggung jawab, dan lainnya. Seperti apa yang diungkapkan oleh Kepala Madin Pondok Riyadlus Sholihin, Ust Ahmad Sya'ir sebagai berikut: "Selama ini pesantren melakukan pembentukan karakter multikultural kepada para santri dengan penerapan yang menyeluruh baik dalam segi tarbiyah (pembelajaran), ta'lim (pengajaran), dan ta'dib (pembentukan karakter/kebiasaan). Pengasuh yang dibantu oleh pendidik (ustad dan asatidzah) dalam pelaksanaan pembelajaran memiliki peran strategis dalam perspektif pembelajaran untuk mewujudkan misi pondok pesantren yang berasas keTuhan an, kebangsaan, kemandirian, karakter multikultural guna mendukung upaya pendidikan Nasional khususnya untuk generasi unggul di masa yang akan datang". ${ }^{27}$

Hal itu didukung dengan kekayaan bahan ajar yang disajikan oleh pesantren kepada para santri. Dengan berbekal pengetahuan agama Islam dan penguatan emosional antara para santri alumni, pengurus dan santri domisili, kerjasama jangka panjang terus bisa dilakukan dalam rangka memperbaiki manajemen lembaga pendidikan pesantren menjadi lebih baik.

Diantara sekian pesantren yang ada di kota Probolinggo, Pesantren Riyadlus Sholihin memiliki kelebihan dan keunikan sebagai pesantren multikultur berbasis akhlakul karimah. Dukungan walisantri dan masyarakat luas, segala fasilitas dan sarana yang ada di pesantren bisa terus dikembangkan dan ditambah mengikuti kebutuhan para santri, terlebih di era modern saat ini, dimana fasilitas modern seperti akses informasi melalui jaringan internet perlu dipikirkan oleh pemangku kebijakan.

Terdapat beberapa metode yang digunakan untuk mencapai target pembentukan karakter para santri di pesantren, antatra lain yaitu: a) pengajian kitab kuning, b) keteladanan Kiai dan Ustadz, c) latihan spiritual/riyadhoh, d) pembiasaan pola hidup, e) pendisiplinan, f) mendidik melalui berorganisasi, g) mendidik melalui ibrah/mengambil pelajaran, h) mendidik melalui mauidzah/nasihat, i) kepanduan/pramuka, j) olah raga, dan k) ilmu kanuragan. ${ }^{28}$ Ada berbagai cara yang digunakan untuk mengimplementasikan pembentukan karakter multikultural dikalangan santri, maka penyelenggaran pesantren berladaskan tujuan, visi dan misi pesantren; menyiapkan agar santri mampu menjadi anggota masyarakat dalam mengadakan hubungan timbal balik dengan lingkungan sosial, budaya dan alam sekitar yang dijiwai suasana keagamaan, dan

27 Ahmad Sya'ir, Wawancara, Probolinggo, 17 Juni 2020).

${ }^{28}$ Bakri dan Werdiningsih, Membumikan Nilai Karakter, 63-78. 
membentuk santri yang cerdas, berilmu, beriman, bertaqwa. Berikut adalah beberapa wujud implementasi pembentukan karakter multikultural santri di Pondok Pesantren Riyadlus Sholihin; a. Toleransi Berbasis Nilai Kitab Kuning

Toleransi melalui penerapan pembentukan karakter multikultural berbasis kitab kuning antara lain yaitu; sebagian kitab kuning bercorak tauhid dan fiqh, dimana didalamnya ada pemahaman tentang pembagian non-muslim dalam kafir yang patut diperangi (harbi) dan kafir yang patut dilindungi (džimmi). Kafir Dzimmi inilah yang mendaptkan perlindungan dan penghormatan luar biasa dalam Islam. ${ }^{29}$ Pesantren Riyadlus Sholihin melaksanakan pengkajian kitab kuning seperti halnya pesantren pada umumnya, karena kitab kuning mencerminkan pemikiran keagamaan yang terlahir dan berkembang sepanjang sejarah peradaban Islam.

Kitab-kitab kuning sebagai ciri khas pondok pesantren terus dilestarikan dan diajarkan kepada para generasi penerus, agar para generasi tersebut tetap berada dalam koridor yang sejalan dengan ajaran-ajaran Islam. Sebagaimana dipahami dikalangan pesantren, bahwa kitab kuning dikarag dan ditulis oleh para ahli agama Islam yang mumpuni dalam bidang keilmuan masing-masing. Baik dalam aspek ibadah mahdhoh maupun yang berkaitan dengan ibadah muamalah.

Dengan demikian terjalinnya proses pendampingan tersebut akan memunculkan karakter multikultural dikalangan santri yang juga bisa berdampak ada proses pembelajaran dia antara masing-masing santri. Karena inti dari pengajaran kitab adalah pengamalan ilmu yang diperoleh untuk dipraktikkan kedalam kehidupan sehari-hari dengan perilaku yang terpuji.

b. Pembiasaan Pola Hidup

Pembiasaan pola hidup sebagai bagian dalam proses pembentukan karakter multikultural santri juga dilaksanakan dalam kehidupan sehari-hari. Tradisi dan pola hidup santri dalam kehidupan sehari-hari di pondok pesantren pada umumnya bertujuan untuk membiasakan para santri melakukan aktivitas yang selalu bermanfaat. Hal itu, terjadi secara turun temurun dari para santri senior hingga diteruskan oleh para santri yunior. Baik dalam kegiatan rutin seperti melakukan bersih lingkungan atau tempat tinggal secara terjadwal atau dengan kesadaran diri sendiri dan sebagainya. Ataupun dalam kegiatan tahun seperti acara haul pendiri dan pengasuh, para santri akan melakukan kegiatan secara bergotong royong mensukseskan acara tahunan di pesantren.

Sepanjang pengamatan peneliti di lapangan, pola belajar para santri pun memiliki karaktersistik unik dan beragam, seperti para santri penghafal nadhom Imriti, ada yang melakukan aktivitas belajar sambil bermain. Dengan kata lain, satu sama lain melakukan 
simulasi kegiatan seperti sebuah perlombaan, namun itu sebatas drama atau akting yang dilakukan sesama santri layaknya melakukan kegiatan perlombaan hafalan.

Setelah melaksanakan shalat jamaah duhur para santri makan siang dengan tertib dan teratur. Terutama bagi para santri yatim-piatu. Masing-masing santri sadar akan pentingnya melaksanakan aktivitas secara interaktif satu sama lain. Tidak sedikit diantara para santri yang makan bersama dengan menggunakan alas sederhana. Dalam tradisi santri hal itu dikenal dengan istilah 'tabek'.

c. Keteladanan Religius Kiai/Pengasuh Pondok dan Ustadz

Peran pengasuh dalam roda kehidupan pesantren sangatlah kuat, secara faktual tindaktanduk pengasuh menjadi sorotan bagi seluruh warga pondok. Keteladan pengasuh dan ustadz di pondok pesantren Riyadlus Sholihin ini sangat mempengaruhi pembentukan karakter, sehingga para santri memiliki inspirator dan motivator yang bisa menjadi acuan untuk kehidupannya sehari-hari.Pesantrenmemiliki orientasi pembentukan santri yang memiliki kemampuan dan pemahaman ilmu-ilmu agama dan mampu mengejawantahkan ilmu tersebut dalam bentuk perbuatan atau perilaku sebagai muslim yang beriman, bertaqwa dan berakhlaq al karimah. ${ }^{30}$

Sebagaimana dipahami bahwa para pengasuh adalah para kiai atau ulama yang memiliki ilmu pengetahuan agama yang luas. Karena itu tidak berlebihan kalau penghormatan kepada para kiai/ustadz seperti layaknya para sahabat menghormati dan memuliakan Rasulullah Saw. Ulama adalah pewaris Nabi, artinya tugas ulama adalah menyebarkan ajaran agama Islam sebagaimana para Nabi menebarkan ajaran Allah Ta'ala diatas muka bumi ini. karena itu, segala aktivitas dan perilaku kesehariannya didasarkan kepada ajaran agama. Bahwa agama mengajarkan kepada para pemeluknya untuk senantiasa menunjukkan perilaku yang terpuji atau akhlakul karimah. Demikian halnya para santri di pesantren, senantiasa diteladankan dengan perilakuk-perilaku terpuji dari para pengasuh dan para ustadz.

Keteladanan dari para pendidik, Kiai/Ulama, para ustadz haruslah ditunjukkan secara gamblang kepada para peserta didik (santri). Karena, dalam proses pembelajaran pendidikan karakter melalui keteladanan perlu dilakukan secara optimal. Keteladan dalam pendidikan karakter menurut Evinna Cinda Hendriana dalam Hasan Baharun bisa diwujudkan dengan mencontoh kepribadian Nabi Muhammad SAW., antara lain; (1) Nabi Muhammad SAW., selalu memulai aktivitas dengan berdoa (berdzikir), biasanya dengan membaca basmalah, atau hamdalah setelah melaksanakan kegiatan, (2) tidak mementingkan diri sendiri, (3) memaafkan orang lain yang berbuat salah, (4) tawadhu' atau merendahkan diri di depan orang lain, dengan

${ }^{30}$ Bakri dan Werdiningsih, Membumikan Nilai Karakter, 51. 
kata lain tidak sombong atau angkuh, (5) tidak dendam kepada orang lain walaupun disakiti, (6) bersikap dermawan (membiasakan diri bersedekah) atau tidak kikir. ${ }^{31}$

\section{d. Penguatan Karakter Peduli Sosial melalui Kegiatan Ro'an}

Para santri memiliki tradisi yang disebut Ro'an. Ro'an sama maknanya dengan bergotong royong. Para santri bergotong royong untuk melakukan pekerjaan apa saja, dari menyelesaikan tugas sehari-hari secara bersama-sama. Ro'an dalam kegiatan istighosah pada umumnya menyiapkan tempat istighosah secara massif agar kegiatan berjalan dengan optimal.

"Kegiatan gotong royong juga dilakukan dalam kegiatan kerjabakti. Seperti yang disampaikan oleh kepala perkumpulan pesantren Ust Suhlal sebagai berikut: Pembentukan karakter multikultural dikalangan santri diwujudkan salah satunya dalam bentuk bersih massal (piketan) pondok setiap hari terutama pagi setelah kegiatan baca AlQur'an yaitu pukul 06.00 WIB, semua kelompok atau kamar yang mempunyai jadwal piketan harus bersama-sama turun langsung, kegiatan merupakan kegiatan rutin seperti menyiram taman, membersihkan kamar, ruang belajar, jaga malam disekitar lingkungan pondok, ikut membangun gedung fasilitas dilingkungan pesantren dan lain-lain. Semua ini dilakukan dengan gotong royong sesuai jadwal piket yang sudah disepakati dengan saling menghargai tanggung jawab masing-masing sehingga dapat mewujudkan nilai basyariyyah (kemanusiaan) yang berdampak pada nilai personal di kalangan santri. ${ }^{32}$

Gotong royong bagi para santri memiliki banyak makna, antara lain; tenggang rasa terhadap sesama, memiliki rasa memiliki terhadap pesantren, melatih keikhlasan dalam berbuat tanpa pamrih dan seterusnya.

Hal tersebut di atas sejalan dengan apa yang di sampaikan oleh Mashuri terdapat beberapa metode yang digunakan untuk mencapai target pembentukan karakter para santri di pesantren, yaitu: a) pengajian kitab kuning, b) keteladanan Kiai dan Ustadz, c) latihan spiritual/riyadhoh, d) pembiasaan pola hidup, e) pendisiplinan, f) mendidik melalui berorganisasi, g) mendidik melalui ibrah/mengambil pelajaran, h) mendidik melalui mauidzah/nasihat, i) kepanduan/pramuka, j) olah raga, dan k) ilmu kanuragan. ${ }^{33}$

e. Karakter Bersahabat/Komunikatif dalam Kelembagaan

Di tengah-tengah persaingan global sekarang ini, penguasaan ilmu pengetahuan dan teknologi sebagai ikon peradaban -dengan tidak menghilangkan ketaqwaan dan moral bagi umat yang beriman tidak mungkin dapat dicapai dengan baik, tanpa melalui pendidikan yang sudah direncanakan sebagai sistem maupun institusi. Maka Pondok melakukan integrasi

31 Hasan Baharun dan Mahmudah, "Konstruksi Pendidikan Karakter di Madrasah Berbasis Pesantren", Jurnal Mudarrisuna, vol. 8, no. 1, Januari-Juni 2018, 168.

32 Suhlal Hadi, Wawancara, Probolinggo, 16 Juni 2020

${ }^{33}$ Bakri dan Werdiningsih, Membumikan Nilai Karakter, 63-78 
dengan beberapa lembaga dinaungan pesantren. Sebagaimana yang diungkapkan oleh pengurus pondok Ust Hafid sebagai berikut:

“... dalam perencanaan pembentukan karakter multikultural dikalangan santri, pesantren dengan beberapa lembaga yang ada dinaungannya selalu berupaya menyiapkan, menyeimbangkan program-program pesantren dengan menyesuaikan perkembangan pengetahuan dan teknologi dengan tanpa mengeyampingkan komponen-komponen pendidikan sehingga mutu pendidikan pesantren bisa dicapai maksimal dengan terwujudnya peran utama di dalam masyarakat...". ${ }^{34}$

Integrasi pembentukan karakter multikultural santri Pondok Pesantren Riyadlus Sholihin yang dengan lembaga-lembaga diniyah dinaungan pesantren dari tingkat Ibtidaiyah sampai Aliyah. Seperti yang diungkapkan oleh Bpk Munir sebagai domisioner kepala madrasah Aliyah sebagai berikut: Mengingat pesantren merupakan cikal bakal pendidikan Islam dan pendalaman keagamaan serta dengan mengacu pada UU Sisdiknas 20/2003 pasal 30, ayat (4) dan UU NO 18 tahun 2019 tentang Pesantren Bab I Pasal 1, 2 dan Bab III pasal 5, di mana pesantren menyelenggarakan pendidikan dalam bentuk lainnya yang terintegrasi dengan pendidikan umum. Maka madrasah dinaungan pesantren ini dilandaskan pada ajaran Islam Ahlussunnah Wal Jamaah, yaitu Madrasah Ibtidaiyyah Riyadlus Sholihin, Madrasah Tsanawiyah Riyadlus Sholihin dan Madrasah Aliyah Riyadlus Sholihin yang berafiliasi kepada Kementrian Agama di samping itu terdapat lembaga Sekolah Menengah Kejuruan yang semua itu diharapkan bisa menjadi suplemen output pesantren untuk mewujudkan generasi santri yang berkarakter multikultural sebagai penerus perjuangan Nabi Muhammad SAW dan sebagai generasi unggul yang bisa menghadapi tantangan zaman. ${ }^{35}$

Dan juga mengadakan bentuk pelatihan-pelatihan SDM di lembaga-lembaga, seperti yang diungkapkan oleh kepala kepesantrenan Ust Hafidz sebagai berikut: Dalam upaya pengembangan pesantren guna menunjang pembentukan karakter multikultural santri, salah satu upaya pesantren adalah dengan meningkatkan mutu para pengajar dengan melakukan pelatihan-pelatihan, workshop, seminar dan delegasi keikutsertaan pada acara-acara peningkatan mutu kepada pihak lain yang relevan untuk pendukung kurikulum program kepesantrenan. Bahkan selain pendidik pesantren juga melakukan pengembangan sumber daya manusia pesantren seperti pelatihan manajemen ekstrakurikuler kepesantrenan, pelatihan jurnalistik, diklat kewirausahaan, kerjasama seminar dengan OJK dan meningkatkan kerjasama antar lembaga dilingkungan pesantren dengan pihak lain yang mendukung ${ }^{36}$. Selain itu juga pendelegasian acara tertentu, seperti partisipasi tenaga pendidik di naungan pesantren pada

${ }^{34}$ Hafid, Wawancara, Probolinggo, 11 Juni 2020.

${ }^{35}$ Misbahul Munir, Wawancara, Probolinggo, 11 Juni 2020

${ }^{36}$ Hafidz, Wawancara, Probolinggo, 11 Juni 2020 
acara Sertifikasi Pembimbing Manasik Haji Profesional angkatan ke-2 (mandiri) tahun 2019 oleh Kanwil Kemenag Jatim dan UIN Sunan Ampel Surabaya yang bekerjasama dengan Forum Komunikasi KBIHU Jatim dan JKSN (Jaringan Kiai-Santri Nasional) di Pondok Pesantren Amanatul Ummah, 18-25 Desember 2019.

f. Pembentukan Karakter Multikultural Santri Terintegrasi dalam Kegiatan Eksrakurikuler

Pesantren Riyadlus Sholihin melakukan beberapa perannya dengan variatif, seperti yang disampaikan oleh salah satu pengurus senior, Bapak Alif seabagai berikut: Riyash al Banjari salah satu wujud potensi hadrah para santri yang sudah dikenal luas di kalangan masyarakat, Ar-Riyash Media sebagai potensi bidang pengembangan jurnalistik dalam upaya meningkatkan skill dan keterampilan para santri yang memiliki bakat penulisan, Wartel arRiyash yang berfungsi sebagai fasilitator komunikasi para santri dengan keluarga, Koperasi arRiyash sebagai wadah pengembangan ekonomi pondok baik dikalangan santri dan masyarakat, Kantin mandiri sebagai usaha mandiri pengembangan usaha mikro yang dikelola oleh IMTARIS, di bidang pertanian pondok mengembangkan kentang, bidang perikanan terdapat ternak ikan lele yang dikelola di dalam area pondok, ${ }^{37}$ selain itu terdapat juga usaha budidaya pohon sengon yang dikelola langsung oleh petani lokal dibantu warga sekitar ${ }^{38}$, usaha lain adalah peternakan dan penggemukan sapi sekitar 40 ekor sapi dewasa, belum sapi anakan yang ada di rumah warga, dan usaha pertanian dengan sistem sewa yang hasil panennya dibuat konsumsi di internal pondok.

Awal tahun 2019, dua santri Pondok Riyadlus Sholihin yang berada di naungan lembaga Madrasah Aliyah diikutkan lomba Se-Jawa Timur di Institut Pesantren KH. Abdul Chalim. Santri kami mendaatkan juara 3 dari kategori cabang lomba Khitobah dengan tema "Mensyiarkan Bahasa Arab di Nusantara Sebagai Wujud Kreatifitas Semangat Generasi Muda" pada tanggal 19 Januari 2019. ${ }^{39}$ Hal tersebut juga memupuk karakter rasa ingin tahu, gemar membaca, kreatif, menghargai prestasi dan lain sebagainya. Setiap santri bebas berkreasi dan perprestasi baik ditingkat lokal, regional maupun nasional dan international. Karena itu, ekstrakurikuler di pesantren akan terus ditambah dan diperbanyak sesuai dengan potensi, minat dan bakat para santri. Dalam hal kegiatan ekstra kajian keagamaan seperti, berikut penjelasan apa yang disampaikan oleh bapak Toha Acara daurah romadhoniyyah ini memberikan kesempatan ara santri untuk memahami pemikiran-pemikiran para ilmuan agama

${ }^{37}$ Alif Ibrahim, Wawancara, PP Riyadlus Sholihin, 10 Juni 2020

38 Lihat https://www.nu.or.id/post/read/60400/pesantren-riyadlus-sholihin-kembangkan-beragam-unit-usaha diakses 10 Juni 2020.

${ }^{39}$ Farihin, Wawancara, Probolinggo, 12 Juni 2020 
dimana pembahasannya dikaitkan dengan kondisi yang relevan dengan permasalahan generasi sekarang. ${ }^{40}$

Pondok pesantren Riyadlus Sholihin memiliki kekhasan tersendiri sehingga digolongkan dalam subkultur tersendiri dalam masyarakat Indonesia sehingga masyarakat memberikan harapan besar dan predikat kepada pesantren, itu mengacu pada tiga fungsi utama, yaitu: (1) pesantren sebagai pusat kaderisasipara pemikir agama (ulama/agamawan). (2) sebagai lembaga pendidikan yang mencetak sumber daya manusia yang unggul. (3) sebagai lembaga pemberdayaan pada masyarakat yang cukup berpengaruh. Karenanya pesantren menjadian bagian dari proses perubahan sosial. ${ }^{41}$

g. Pembentukan Karakter Tanggungjawab dan Jujur melalui Wadah Organisasi

Berorganisasi, juga dijadikan oleh pesantren untuk membentuk karakter multikultural santri, bahkan kegiatan berorganisasi menjadi salah satu faktor penting bagi perkembangan keilmuan dan karier santri. Menyadari pentingnya budaya kebersamaan cukup signifikan dalam meningkatkan partisipasi para santri berperan aktif dalam pengembangan ilmuilmuagama, pengembangan ekonomi, sosial kemasyarakatan yang berkaitan dengan SDM yang selaras dengan visi dan misi pendidikan Pesantren, muncul ide atau gagasan dari beberapa santri dan asatidz yang mengingingkan terbentuknya sebuah organisasi sebagai wadah pengembangan minat dan bakat serta pengabdian terhadap Pesantren. ${ }^{42}$

Salah satu organisasi internal pesantren adalah ITMARIS (Ittihadut Thullab Ma'bad Riyadlus Sholibin), sebuah wadah kegiatan pengkaderan santri yang berdiri dibawah naungan Pondok Pesantren Riyadlus Sholihin yang bertujuan untuk mengembangkan dan memajukan minat dan bakat santri serta sebagai pendukung kemajuan Pondok Pesantren Riyadlus Sholihin sehingga terwujudnya sistem keamanan, kebersihan, kesehatan dan bidang-bidang lainnya yang lebih baik lagi. Organisasi santri Riyadlus Sholihin ini juga mengimplementasikan pembentukan karakter multikultural dikalangan santri, bukan hanya pada kegiatan rutin yang sudah diprogramkan saja, seperti adanya tradisi khas dan unik pada perayaan pernikahan santri senior/ustad. Seperti yang disampaikan oleh Abdul Kholik selaku ketua ITMARIS "tradisi ini adalah tradisi yang memang kami lakukan untuk memberikan sebuah kenangan kepada para ustadz yang akan berumahtangga dan juga pindah dari pondok“. Sikap ini adalah

\footnotetext{
40 Ahmad Toha Maksum, Wawancara, Probolinggo, 12 Juni 2020

${ }^{41}$ ToR PW RMI Jatim, Social Change di Tengah Perubahan yang Terjadi (Sidoarjo, 2020)

42 https://web.facebook.com/ 416877555073031/ photos/ ikhwanuna-rohimakumullah- kali-ini- al-faqier-akanmengenalkan -lebih- dalam-tentang / 673965569364227, diakses 10 Juni 2020
} 
salah satu wujud pembentukan karakter multikultural bahkan tradisi ini menjadi tontonan masyarakat dan menarik simpati pengguna jalan. ${ }^{43}$

Sedangkan organisasi eksternal dari naungan lembaga-lembaga pesantren yang Riyadlus Sholihin banyak berpartisipasi baik secara personal, komunal, atau melalui organisasi kemasyarakatan, sebagai upaya nyata dalam imlementasi pembentukan karakter multikultural santri, sebagaimana yang diungkapkan oleh Toha Maksum salah Pengurus Pondok, sebagai berikut: ${ }^{44}$ a) Pengajian Umum dalam rangka peringatan Maulid Nabi Muhammad SAW. dan Haul Masyayikh Pondok Pesantren Riyadlus Sholihin, Kamis 12 Desember 2019, b) Partisipasi Pondok Riyadlus Sholihin dalam rangka Silaturrahmi Wawasan Kebangsaan yang disampaikan oleh Kolonel Inf Zainuddin (Komandan Korem 083/Baladhika Jaya) di Pondok Pesantren, c) Partisiasi santri Riyadlus Sholihin pada acara Jalan Sehat Millenial Road Safety Festival 2019 dengan Polres kota Probolinggo yang bertema "Mewujudkan Millenial Cinta Lalu Lintas Menuju Indonesia Gemilang”, d) Partisipasi santri Riyadlus Sholihin dalam acara peringatan 'Hari Lingkungan Hidup Se-Dunia, di Kompleks UPT Pelabuhan Perikanan Mayangan Kota Probolinggo, pada hari Minggu 28 Juli 2019 yang bertema "Biru Langitku, Hijau Bumiku"45, e) perwakilan partisipasi santri pada acara Pekan Hari Santri Nasional 2019 "Bedah Buku” Kiai Organisator Membangun NU Bersama KH. Mahfudz Siddiq di Lapangan Kodim 0820 Kota Probolinggo, 20 Oktober 2019.

h. Pembentukan Karakter Multikultural Santri dengan Bentuk Kepanduan Pramuka

Gerakan Pramuka dipahami sebagai suatu gerakan pendidikan kaum muda yang bertujuan untuk mendidik dan membina kaum muda Indonesia guna mengembangkan mental, moral spiritual, emosional, sosial, intelektual dan fisik (SESOSIF). Seperti yang diungkapkan oleh pendamping Pramuka Riyadlus Sholihin bahwa pembentukan karakter basyariyyah dalam ke-multikultural-an juga santri terwujud dalam partisipasi Satuan Komunitas Pramuka Ma'arif NU se Jawa Timur. Pembina Pramuka ${ }^{46}$ Pondok Riyadlus Sholihin, mengatakan bahwa setelah lulus seleksi SAKO Ma'arif Kota Probolinggo pada 17 Juli 2019, sejumlah sembilan santri Riyadlus Sholihin mengikuti lomba pramuka dengan acara Giat Santri Nusantara 1 se-Jawa Timur di Ma'hadul Qur'an Adz-Dzikraa Lamongan Arjasa Situbondo. Kesembilan peserta adalah santri yang berada di naungan lembaga madrasah Aliyah dan Kejuruan pondok Riyadlus Sholihin. Selaras dengan pendapat Maskuri dan Diyah bahwa target pembentukan karakter para santri di pesantren, antatra lain yaitu: a) pengajian kitab kuning, b) keteladanan Kiai dan

\footnotetext{
43 http:/ /www.gempurnews.com/2019/01/10/tradisi-unik-di-ponpes-riyadlus-sholihin/ diakses 10 Juni 2020

44 Toha Maksum, Wawancara, PP Riyadlus Sholihin, 12 Juni 2020.

45 Qodir, Wawancara, Probolinggo, 12 Juni 2020.

${ }^{46} \mathrm{M}$ Khoirudin, Wawancara, Probolinggo, 12 Juni 2020.

62 | Tarbiyatuna: Jurnal Pendidikan Islam; Volume 14, Nomor 1, Februari 2021 p-ISSN: 2085-6539; e-ISSN: 2242-4579, 46-68
} 
Ustadz, c) latihan spiritual/riyadhoh, d) pembiasaan pola hidup, e) pendisiplinan, f) mendidik melalui berorganisasi, g) mendidik melalui ibrah/mengambil pelajaran, h) mendidik melalui mauidzah/nasihat, i) kepanduan/pramuka, j) olah raga, dan k) ilmu kanuragan. ${ }^{47}$

\section{Hasil Implementasi Pembentukan Karakter Multikultural Santri}

Karakter santri yang multikultural menjadikan pola berpikir dan perperilaku yang saling menghargai satu dengan yang lain, disebabkan adanya keteladanan secara turun termurun dari para kiai/pengasuh dan pengurus serta para satri senior (alumni). Keberadaan para santri senior sebagai pengurus di pesantren juga sering melakukan koordinasi melalui wadah pertemuan alumni maupun dalam kegiatan tahunan dalam rangka imtihan dan atau peringatan haul pendiri dan pengasuh.

Wadah silaturrahmi tersebut dijadikan momen yang berharga bagi para santri senior (alumni) dengan para pengurus dan tokoh masyarakat setempat untuk saling melakukan evaluasi dan berbagi informasi terkait problema yang sedang dialami pesantren. Beberapa santri senior yang masih berada di pesantren terus melakukan koordinasi secara musyawarah untuk membahas hal-hal yang akan menjadi kebijakan baru di pesantren. Keberperanan para santri senior dalam beberapa aspek menjadi referensi bagi pengurus dalam merekomendasikan kegiatan-kegiatan yang dikembangkan di pesantren.

a. Aspek Sosial Pendidikan

Mengingat banyaknya lembaga pendidikan yang dikembangkan dipesantren Riyadlus Sholihin mulai pendidikan anak usia dini hingga perguruan tinggi, memicu para santri senior dan pengurus memenuhi sumber daya manusia yang unggul secara kuantitas dan kualitas. Selain menjadi pengajar di madrasah diniyah, beberapa santri senior telah mengabdikan diri sebagai pendidik tetap (Guru Tetap Yayasan) di lembaga-lembaga pendidikan formal Riyadlus Sholihin.

Para santri senior yang sekaligus pengurus aktif pesantren harus berbagi waktu dalam manajemen pengelolaan lembaga pendidikan formal dan non formal. Hal itu dilakukan sebagai wujud kepedulian yang tinggi dan solidaritas terhadap almamater dalam rangka menggapai cita-cita pesantren yang telah digariskan oleh pendiri dan pengasuh.

Sumber daya manusia (guru/ustadz) secara umum sudah menerapkan pendidikan sepanjang hayat. Hal itu dibuktikan dengan peningkatan jumlah lembaga formal di Pesantren

${ }^{47}$ Bakri \& Werdiningsih, Membumikan Nilai Karakter, 63-78. 
Riyadlus Sholihin terbilang cukup signifikan dalam kurun 10 tahun terakhir, karena selain tetap aktif sebagai pendidik (guru tetap yayasan) khususnya yang bersertifikasi, para ustadz tersebut masih dengan sukarela mengabdikan diri mengajarkan ilmu agama kepada para santri yunior melalui kegiatan madin dan kegiatan terjadwal lainnya.

Penerapan kurikulum terintegrasi antara umum dan agama menjadikan tenaga pendidik harus memiliki semangat tinggi (cinta ilmu) dan inovasi yang terus menerus dalam rangka mengejar keterampilan dan kompetensi yang relevan dengan para peserta didik. Artinya, dalam beberapa kesempatan para ustadz harus melaksanakan dan menyelenggarakan pelatihan dan diklat-diklat penunjang menajemen pendidik yang professional diluar kewajibannya sebagai Guru Tetap Yayasan Tersertifikasi. Begitu pula para Ustadz yang mengabdikan diri hanya sebatas untuk mengajar di Madin, harus selalu melakukan pembaharuan terkait manajemen kelas dan materi ajar.

b. Aspek sosial Politik

Keteladan para pengasuh baik Habib Ali dan Habib Hadi kepada para pengurus dalam rangka menjaga kualitas SDM Santri yang unggul secara agama (berakhlakul karimah) dan berwawasan kebangsaan yang kuat, perlu dilakukan kegiatan-kegiatan yang menjembatani para santri senior yang berada di luar pesantren untuk terus melakukan pengawasan dan pendampingan kepada para santri yang domisili di pesantren. Hal itu menjadi penting, mengingat peran dari para pengasuh di pesantren masih kurang intensif dikarenakan kesibukan dalam mengayomi masyarakat luas di luar pesantren. Bahkan salah satu pengasuh (Habib Hadi) saat ini masih menjabat sebagai Wali Kota Probolinggo. Sehingga intensitas dan mobilitas pengasuh terhadap para pengurus dan santri perlu penguatan emosional dalam internal pesantren. Padahal, apa yang ditunjukkan oleh pengasuh merupakan keteladan bagi santri bagaimana bersikap dan berperilaku yang baik sebagai warga negara Indonesia. Jadi, ketika ada pengasuh yang terlibat aktif di bidang politik maka para santri pun perlu menekuni dan memahami aspek politik berasaskan Islam yang baik. artinya, politik bukan bisa menjadi jembatan dakwah Islam kalau di tekuni dengan baik. karena itu para santri masa depan perlu belajar lebih banyak terntang literasi politik kepada para pengasuh yang telah aktif terlibat di dunia perpolitikan, demi mengisi masa kemerdekaan yang lebih baik di bidang politik. Terlebih menurut Dhofier, adapun sisi yang menarik (unik) pendidikan di pesantren itu adalah antara kiai atau pendidik dengan para santri ada (ikatan kuat) perasaan hormat dan kepatuhan. Penghormatan santri dan kepatuhan tersebut berlaku seumur hidup. Perasaan hormat dan kepatuhan santri yang meliputi semua aspek kehidupannya merupakan ikatan batin yang kuat. 
Kendatipun, adanya pembatasan kehidupan di dalam pesantren. Sehingga para santri hidup dalam rutinitas yang terjadwal ketat dan tidak mudah bergaul dengan masyarakat luar. Namun, pola tersebut dapat efektif membentuk karakter santri, yang canggung dalam bergaul. Karena itu, kegiatan sosial keagamaan yang dilakukan pesantren masih belum cukup untuk menguatkan emosioal para santri domisili. Terlebih intensitas interaksi antara para pengurus dengan santri sebatas pertemuan formal di dalam pembelajaran diruang kelas. Sedangkan intensitas antara santri senior dengan para santri domisili belum terwadahi secara massif melalui pertemuan-pertemuan khusus. Kendatipun kegiatan keagamaan secara rutin dalam istighosah bulanan selalu dilaksanakan, namun dalam proses pendidikan dan pembentukan karakter antara lintas generasi dan lintas domisili sesame santri di pesantren Riyadlus sholihin masih sangat perlu perhatian lebih inensif. Bukan hanya sebatas interaksi yang terjalin dalam moment pemilukada baik pusat maupun daerah. Melainkan harus terbangun emosional para santri senior dengan yunior melalui literasi politik dalam kajiankajian yang terintegrasi dalam kurikulum pesantren. Karena, kurikulum yang kaku (tidak relevan) dengan kebutuhan masyarakat masa depan justru akan menjadikan peserta didik menjadi taqlid fanatik.

Sebagaimana dalam gambaran yang disampaikan Zaini, bahwa Pesantren dan Politik adalah dua istilah yang tidak bisa disamakan, namun memiliki persinggungan dalam realitas kehidupan sosial. Sebagai pijakan, pemikiran pendiri NU, KH. Hasyim Asy'ari tentang pendidikan Islam, pesantren dan perannya dalam kehidupan berbangsa. Pada konteks sejarah, eksistensi pesantren dimaksudkan untuk mempertahankan nilai-nilai keislaman prioritas pada pendidikan. Pesantren juga berusaha untuk mendidik para santri dengan harapan dapat menjadi orang-orang yang berwawasan luas dan mempunyai karakter. Zaini menambahkan bahwa para santri berkarakter dapat merefleksikannya dalam masyarakat. Hal ini telah diuraikan oleh KH. Hasyim Asy'ari, dalam beberapa karya, yang dengan jelas menegaskan bahwa tujuan pendidikan Islam tidak hanya berhenti pada tingkat kognitif semata. Melainkan juga dan terutama pada pengamalan ilmu yang telah diperoleh, yang disebut dengan ilmu bermanfaat ('ilm nafi ). Hal inilah yang menjadi keunggulan pendidikan pesantren, mampu mengkolaborasikan kecerdasan emosional, intelektual, dan spiritual, dalam membentuk karakter.

c. Aspek Organisasi kemasyarakatan

Organisasi sosial masyarakat bagi para santri sudah tidak asing lagi, dikarenakan dipesantren para santri telah dilatih mengikuti berbagai organisasi santri dan atau siswa. Dengan pengalaman hidup berorganisasi, para santri diharapkan bisa menjadi indivu yang 
mampu beradaptasi secara optimal ditengah kehidupan masyarakat apapun profesi dan pekerjaannya. Pada umumnya, para santri yang telah alumni akan menerjunkan diri aktif sebagai aktivis organisasi yang sesuai dengan aliran dan ajaran di pesantren yaitu berbasis aswaja. Disinilah peran santri di organisasi NU menjadi lumrah dan sebagai sebuah keharusan. Jikalau didapati ada santri yang belum aktif di organisasi kemasyarakatan maka kesantriannya perlu dipertanyakan.

\section{Kesimpulan}

Adapun kesimpulan artikel ini, pertama; perencanaan pembentukan karakter multikultural pondok pesantren Riyadlus Sholihin yang dilakukan adalah sebagai berikut (1) pondok pesantren melakukan perencanaan dengan dasar dan tujuan, visi dan misi yang jelas dalam pembentukan karakter multikultural, (2) merumuskan tujuan, tata tertib, larangan, sanksi, kewajiban dan proses pelaksanan pembelajaran untuk membentuk karakter multikultural, (3) merumuskan kurikulum yang memuat pelajaran karakter bersumber dari kitab-kitab akhlak. (4) merancang strategi dan mempertahankan kitab kuning sebagai ciri khas pesantren menggali sumber pembentukan akhlak/karakter multikultural.

Kedua; Implementasi pembentukan karakter multikultural dikalangan santri pondok pesantren Riyadlus Sholihin dapat dibuktikan dengan berbagai kegiatan yang dapat membentuk karakter multikultural santri seperti; a) pengkajian kitab kuning, b) pembiasaan pola hidup, c) keteladan kiai/pengasuh pondok dan ustad, d) pembentukan karakter multikultural dalam wujud gotong royong, e) pembentukan karakter multikultural yang terintegarasi dalam kegiatan ekstrakurikuler, f) integrasi pembentukan karakter multikultural dengan lembaga, g) pembentukan Karakter Multikultural Santri melalui Berorganisasi, dan h) pembentukan karakter multikultural santri dengan bentuk kepanduan / Pramuka.

Ketiga; Hasil dari implementasi pembentukan karakter multikultural dikalangan santri pondok Riyadlus Sholihin yakni terbentuknnya pribadi santri yang memiliki spiritualitas dan religiusitas kuat, kemampuan bekerjasama dengan saling menghargai dan menghormati orang lain sehingga mampu menjadi generasi unggul siap berkompetisi positif dalam menggapai prestasi di masa mendatang.

\section{Referensi}

Afidah, Titin Nur “Konsep dan Paradigma Pendidikan MultikulturaP”, Skripsi UMM. 2017

Akbar, Nadzmi \& Rifat. Muhammad "Pengembangan Karakter Multikultural Santri Pada Pondok Pesantren Salafiyah di Kalimantan Selatan". Alhadharah: Jurnal Ilmu Dakwah, Vol. 18, No. 2, 28-38 Fakultas dakwah dan Ilmu Komunikasi UIN Antasari, 2019 
Bakri, Maskuri; Werdiningsih, Dyah, Membumikan Nilai Karakter Berbasis Pesantren, cet. Kedua, Jakarta; Nirmana Media. 2017

Cahyono, Heri. "Pendidikan Multikultural di Pondok Pesantren: Sebagai Strategi dalam Menumbuhkan Nilai Karakter", At-Tajdid, Volume.1 , No 1 (Januari-Juni, 2017)

Departemen Agama RI, Al-Qur'an dan Terjemahannya", Semarang: CV As Syifa'. 1993

Dali, Zulkarinain.“Pendidikan Islam Multikultural”, Nuansa, Vol. X, No.1 (Juni, 2017)

Fatoni, Muhammad Sulton, Kapital Sosial Pesantren, Jakarta: UI Press, 2015.

Hasan, Muhammad."Inovasi dan Modernisasi Pendidikan Pondok Pesantren", KARSA: Jurnal Sosial dan Budaya Keislaman, Vol. 23, No. 2 (Desember 2015)

Hilman, Cecep. Imlementasi Pendidikan Karakter Berbasis Multikultural di Sekolah, Sukabumi: STAI Sukabumi, 2017.

Huzaimah, " Imlementasi Nilai-Nilai Pendidikan Multikultural dalam pembelajaran PAI ; telaah terhadap hidden curriculum di SMAN1 dan SMAN2 Grabag". Thesis Program Pascasarjana (Jawa Tengah: IAIN Salatiga, 2018).

Ibrahim, Rustam."Pendidikan Multikultural : Pengertian, Prinsip dan Relevansinya dengan Tujuan Pendidikan Islam”, ADDIN Vol, 7, No.1 (Februari 2013)

Jamilah, "Pembentukan Karakter Berbasis Pendidikan Multikultural di Yayasan Pondok Pesantren Modern Yatim dan Dhuafa Madania Yogyakarta". Tesis Magister Pendidikan Islam (Yogyakarta: UIN Sunan Kalijogo Yogyakarta, 2016).

Primawati, Laurencia."Pembelajaran Multikultural melalui Pendidikan Multikultural Berbasis Nilai Kebangsaan”, JUPIIS, Vol. 5, No. 2 (Desember 2013)

Ma'arif \& Cahyani, "Pendidikan Multikultural Sebagai Pembentukan Karakter Peserta Didik", Ta'lim: Jurnal Pendidikan Islam, Vol. 2, No. 2 (2019)

Muchasan, Ali. "Pendidikan Islam Multikultural di Pesantren", Inovatif, Vol. 4, No. 1 (Pebruari 2018)

Ningsih, Tutuk. Implementasi Pendidikan Karakter, cetakan pertama. Purwokerto: STAIN Press, 2015

Rohman A. \& Ningsih Y.E. Pendidikan Multikultural: Penguatan Identitas Nasional di Era Revolusi Industri 4.0, Seminar Nasional Multidisiplin. Jombang: UNWAHA, 29 Setember 2018.

Ramadhon, Joan, "Upaya Pengurus Pondok Pesantren Terhadap Penanaman Nilai-nilai Pendidikan Multikultural di Pondok Pesantren Hidayatul Mubtadiin Jati Agung Lampung Selatan”, Skripsi Fakultas Tarbiyah dan Keguruan (Lampung: UIN Raden Intan, 2019)

Sudajat, Ajat, "Mengapa Pendidikan Karakter", Jurnal Pendidikan Karakter, Vol. 1, No. 1, (2011).

Rofie, Moh. "Manajemen Kurikulum Pendidikan Agama Islam Berbasis Pesantren", Jurnal Reflektika, Vol. 12, No. 2, (Juli-Desember, 2017)

Setiyawan, Deny. Implementasi Pendidikan Karakter di Era Global, Prosiding Seminar Nasional Tahunan Fakultas Ilmu Sosial Universitas Negeri Medan 2017

Siregar, Lis Yulianti S. Tantangan Pendidikan Islam di Era Multikultural. Batusangkar International Conference 1, 15 -16 Oktober 2016.

Syafaruddin dkk, Inovasi Pendidikan (Suatu Analisis Terhadap Kebijakan Baru Pendidikan)", Medan: Perdana Publishing, 2012 
Wihardit, Kuswaya."Pendidikan Multikultural: Suatu Konsep, Pendekatan dan Solusi", Jurnal Pendidikan, Vol. 11, No. 2 (September 2010)

www.riyadlussholihin.com diakses 10 Juni 2020

http://itmarisriyadlussholihin.blogspot.com/2017/03/itmaris-riyadlus-sholihin-ketapang.html diakses pada 10 Juni 2020

http://www.gempurnews.com/2019/01/10/tradisi-unik-di-ponpes-riyadlus-sholihin/ diakses pada 10 Juni 2020

https://www.nu.or.id/post/read/60400/pesantren-riyadlus-sholihin-kembangkan-beragam-unitusaha diakses 10 Juni 2020

https://www.laduni.id/post/read/47816/pesantren-riyadlus-sholihin-probolinggo

\section{Wawancara}

Hafidz, Wawancara, Probolinggo, 11 Juni 2020.

Alif Ibrahim, Wawancara, Ketapang, 12 Juni 2020.

Tauhid, Wawancara, MA Riyadlus Sholihin, 10 Juni 2020.

Abdul Manap, Wawancara, Probolinggo, 28 Juni 2020.

Ahmad Sya'ir, Wawancara, Probolinggo, 17 Juni 2020.

Suhlal Hadi, Wawancara, Probolinggo, 16 Juni 2020.

Misbahul Munir, Wawancara, Probolinggo, 11 Juni 2020.

Farihin, Wawancara, Probolinggo, 12 Juni 2020.

Ahmad Toha Maksum, Wawancara, Probolinggo, 12 Juni 2020.

Toha Maksum, Wawancara, PP Riyadlus Sholihin, 12 Juni 2020.

Qodir, Wawancara, Probolinggo, 12 Juni 2020.

M Khoirudin, W awancara, Probolinggo, 12 Juni 2020. 